\title{
POLÍTICAS PÚBLICAS E TERRITÓRIO: ANÁLISE DA AGENDA PÚBLICA NA SEGUNDA DÉCADA DO SÉCULO XXI
}

\author{
PUBLIC POLICIES AND TERRITORY: ANALYSIS OF THE PUBLIC AGENDA IN THE SECOND DECADE OF THE 21ST \\ CENTURY
}

O início do século XXI foi marcado pelo fortalecimento dos compromissos do poder público com as políticas sociais no Brasil. Os avanços experimentados na Educação, Saúde e Assistência Social foram acompanhados de políticas territoriais urbanas e regionais. As áreas de habitação popular, saneamento e mobilidade urbana receberam mais atenção e recursos, ainda que sem alcançar os resultados esperados.

A edição do Estatuto da Cidade (2001) e a criação do Ministério das Cidades (2003) foram importantes marcos nas políticas urbanas, seguidos da proposição de uma Política Nacional de Desenvolvimento Regional (2004). O governo federal prometia retomar uma atuação mais ativa nas políticas territoriais, a exemplo do que já ocorrera na década de 1970, ainda que em contexto de descentralização e fortalecimento dos governos locais.

O crescimento econômico experimentado a partir de 2005 permitiu a expansão dos gastos sociais e animou os defensores das políticas públicas a avançarem em suas agendas propositivas. Assim, foram editadas diversas leis que marcaram a instituição de políticas nacionais, como a de Habitação Social, a de Saneamento e Resíduos Sólidos e a de Mobilidade Urbana. Essa "era de planos" culminou com a entrada em vigor do Estatuto da Metrópole, em 2015. Importante lembrar que essa dinâmica se deu em um contexto que, a despeito do federalismo tripartite, a União manteve-se protagonista na distribuição de recursos, privilegiando a interlocução com Municípios e enfatizando a perda de protagonismo dos Estados após a redemocratização.

Esta agenda prometeu mais do que conseguiu entregar, nunca é demais lembrar. Mesmo assim, é inegável a produção de avanços institucionais importantes que, em regra, se deram a partir de amplo debate público. No entanto, a perda de dinamismo econômico associado ao questionamento da capacidade do governo federal seguir liderando aquele projeto na segunda década do século XXI suscitou o questionamento sobre as possibilidades e os limites das políticas públicas territoriais em curso no país.

As crises políticas e econômicas que emergem na segunda década do século XXI produzem inúmeras implicações para a política urbana nacional. O objetivo desta edição especial da Revista GEO é justamente destacar alguns desses desdobramentos, considerando que, se por um lado tais crises podem provavelmente estar afetando negativamente o avanço normativo da política urbana, por outro, identifica-se também a oportunidade política para a emergência de novos movimentos sociais urbanos que podem impactar a política urbana. 
Para alcançar tal objetivo, reunimos um conjunto de artigos de professores pesquisadores seniores e alguns doutorandos que atuam nas áreas das políticas urbanas e regionais, grande parte dos quais com o foco no território fluminense.

Num primeiro bloco, incluímos os principais temas da política urbana, com uma abordagem generalista. Em seguida, destacamos aspectos jurídicos da agenda urbana. Um terceiro bloco foi dedicado à análise de aspectos de finanças municipais visando melhor entendimento sobre o financiamento das políticas territoriais dos executivos municipais, seguido de artigos que trazem o impacto de novos movimentos sociais sobre a política urbana. Na sequência, foram reunidos artigos que tratam de diferentes aspectos da economia e do território fluminense, destacando-se questões econômicas, demográficas e ambientais, além de análise da crise econômica que tem sido mais intensa no Estado do Rio de Janeiro.

Angela Penalva Editora convidada para o dossiê da revista Geo UERJ

Gláucio Marafon Editor da revista Geo UERJ

Pedro Vasques Editor convidado para o dossiê da revista Geo UERJ 